\title{
Land Rights in Countries in Transition: A Case Study of Human Rights Impact of Economic Land Concessions in Cambodia
}

\author{
Surya P. Subedi ${ }^{1}$
}

\section{INTRODUCTION}

Disputes relating to land or land rights is not new in law. In many countries land law is one of the oldest areas of law. Various wars have been fought throughout human history for land, whether between states or between communities or between individuals within the same community. Land ownership has been regarded as evidence of wealth, prestige and power in most countries. The right to property in both national and international law has its origins in land ownership and land rights.

However, with the introduction of collective farming or commune or state ownership of land in countries with socialist political systems, a fundamental change took place in the nature and scope of land rights in such countries. After the demise of communism in Europe, the collapse of the Soviet Union, and China's decision to embark on the road to economic liberalization, land rights and land disputes returned to occupy center stage in domestic policy making in countries with socialist tendencies. This is because some form of individual right to property or land came into existence with the opening up of the economy in these countries. With this recognition of the right to property, including land, the tendency on the part of the rich and powerful, whether politically or militarily, to grab land for speculative purposes has been a major problem in many countries with a socialist political system or a socialist past.

What is more, land acquisition by the government or local councils for various social and economic purposes under schemes such as economic

1 LL.B (Tribhuvan); LL.M with Distinction (Hull); D.Phil. (Oxford); Barrister of the Middle Temple; Professor of International Law, University of Leeds; United Nations Special Rapporteur for Human Rights in Cambodia. 
land concessions that lack in transparency, accountability, due process, and adequate compensation, and involve forcible eviction of especially the poor, the indigenous and traditional communities, and those on the margins of the society, has posed its own challenges to countries in economic and political transition. The situation in Cambodia is particularly illustrative of the challenges for a number of historical, political and social reasons.

It is in this context that this article ${ }^{2}$ aims to provide an assessment of the human rights impact of economic land concessions (ELCs) and other land concessions in Cambodia (generally referred to as "land concessions" throughout the article unless otherwise specified). It includes not only an analysis pertaining to agro-industry (for example, rubber, sugar, acacia, and cassava plantations), but also to concessions for mining, oil and gas, forestry, and concessions for the purposes of tourism, property development, and large scale development projects, such as hydropower dams.

The situation in Cambodia is a particularly interesting one. At the outset, it should be noted that historical circumstances, including policies of the Khmer Rouge regime, have led to the proliferation of land disputes that the government is trying to manage. It should also be noted that Cambodia as a developing country may wish to utilize its land and natural resources in order for the country to develop and become more prosperous.

2 This article is based on an earlier report submitted to the United Nations Human Rights Council in September 2012 by the present author in his capacity as the United Nations Special Rapporteur on the situation of human rights in the Kingdom of Cambodia. A Human Rights Analysis of Economic and other Land Concessions in Cambodia, U.N. Doc. A/HRC/21/63/Add.1 (Sep. 24, 2012). Upon reading this report and realising its significance for the broader intellectual and academic community, the Editor-in-Chief of the Asian Yearbook of International Law, Professor Kevin Tan of the National University of Singapore Law School, invited the present author to convert it into a scholarly article for publication in the YeArbook. The present author would like to thank Professor Kevin Tan for this invitation. He also wishes to thank several members of staff in the Cambodia Office of the United Nations Office of the High Commissioner for Human Rights and particularly Ms Taryn Lesser, Ms Bophal Keat, Mr James Heenan and Mr Karona Ean for their valuable assistance in collecting data and information for this study. The views expressed in this article should be treated as the personal and academic views of the author and not necessarily the views of the U.N. or the views of the present author in his capacity as the United Nations Special Rapporteur for Cambodia. 
Nevertheless, this article argues that land concessions should be granted and managed within a sound legal and policy framework, with due consideration for and consultation with those who will be affected, and with the sustainable use of natural resources in mind. Cambodia, as an emerging market, is vulnerable to an international reputation for insecure investment in the land sector. The current climate of development - characterized by uneven transparency, inadequate consultation, and participation which is not inclusive - is unsustainable and likely to hamper future national economic growth.

This article concludes that the human cost of many such concessions has been high and the poorest of the poor have suffered the most. Therefore, human rights should be at the heart of land concessions for positive impact. It is not clear how much the people of Cambodia have benefitted from ELCs and many such concessions often have a dimension of corruption because they operate behind a veil of secrecy. There are far too many land disputes associated with economic concessions that remain unresolved and they are having a negative impact on the lives and livelihood of the rural and urban poor, the indigenous people, and other traditional communities. The Cambodian government should be transparent in dealing with economic concessions and protect the lives and livelihood of such people when negotiating such concessions with companies, both foreign and national, and hold them accountable over land disputes. The present author is of the view that the development of Cambodia's land and natural resources could have a positive impact on the lives of all Cambodians if done in a sustainable and equitable manner and within the framework of the human rights obligations of Cambodia.

\section{LAND CONCESSIONS IN CAMBODIA}

A land concession is a contract between the government and a state or private actor that gives that actor specific rights (for example, exclusive rights to manage and harvest the land) normally for a long period of time, but not ownership. ${ }^{3}$ Concerns about the impact of land concessions in

3 See generally L Cotula et al., Land Grab or Development Opportunity? Agricultural Investment And International Land Deals In Africa, IIED/FAO/IFAD (2009); K Barney, A Note on Forest Land Concessions, Social Conflicts, and Poverty in 
Cambodia began in the 1990s when human rights organizations started to receive complaints about human rights violations on concession land. ${ }^{4}$ The human rights impacts of land concessions have been the subject of research by OHCHR and of reports by several successive Special Representatives of the Secretary-General (hereafter SRSGs) for human rights in Cambodia. ${ }^{5}$ The first SRSG, Michael Kirby, visited a plantation concession in January 1996 in Rattanakiri province and expressed concern about the impact of ELCs on the human rights and livelihoods of rural communities. In his subsequent report to the then Commission on Human Rights, he recommended that "the complaints of villages concerning non-consultation, the use of armed guards, the presentation for signature of an unexplained contract, the shooting of cows which wander onto concession areas and the feared endangerment of village survival and security of traditional

the Mekong Region proceedings: International Conference on Poverty Reduction and Forests, Proceedings.: International Conference on Poverty Reduction and Forests, Bangkok (2007); S.M. Borras et al., Towards a better understanding of global land grabbing: an editorial introduction, 38 The Journal of Peasant Studies 209 (2011); O. De Schutter, How Not to Think of Land-Grabbing: Three Critiques of Large-Scale Investments in Farmland, 38 The Journal of Peasant Studies 249 (2011); Ruth Hall, Land Grabbing in Southern Africa: The Many Faces of the Investor Rush, 38 Review of African Political Economy 193 (2011); Food and Agric. Org. on U.N., Voluntary Guidelines on the Responsible Governance of Tenure of Land, Fisheries and Forests in the Context of National Food Security Food and Agriculture Organization of the United Nations (2012); A. Zoomers, Globalisation and the Foreignisation of Space: Seven Processes Driving the Current Global Land Grab, 37 The Journal of Peasant Studies 429 (2010).

4 For example, see the archived reports of Global Witness, including Going Places, March 1998, and Sara Colm, The effects of oil palm plantation development on indigenous communities, Rattanakiri province, Cambodia, Natural Resource Management Project, 1996.

5 For a historical overview of land concessions, see the 2004 SRSG Report, 10-14. 
sites of grave, pasture and farming land be resolved without delay, justly and according to the law."6

Michael Kirby's successor, Thomas Hammarberg, continued to examine the human rights impact on indigenous peoples caused by land and logging concessions, and he urged the government, among other things, to officially recognize their use of land, forests and other natural resources, and their distinct and unique identity, culture and way of living, as well as the role of indigenous peoples in managing and preserving forests and biological diversity. He recommended that "villages, lands and forests used by the Highland Peoples be clearly mapped and preserved from any current and future commercial concession or similar use. Local commune forestry projects should be recognized and supported. Public and private projects should only take place after due consultation with the peoples affected, and social, environmental and cultural impact assessment studies have been carried out."7

By the 2000s, Thomas Hammarberg's successor, Peter Leuprecht, studied in-depth the impact of the land concession system from a human rights perspective, which was the subject of a 2004 report. The report explained the history and current practice of land concessions, including the early development of the concession system, and focused on the impacts on the human rights and livelihoods of local communities. The aim of the report was to contribute to public understanding of the issues and to help bring about changes in policy and practice to assist Cambodia's rural poor and future generations. Leuprecht, expressing shock at the situation he witnessed, assessed that the "policies are wrong....companies have been given rights over land that are very similar to ownership, and yet they have little or no regard for the welfare of the people; and they contribute little to state revenue....They are not reducing poverty in Cambodia, and they are allowing the continued plundering of its natural resources." ${ }^{8} \mathrm{He}$ called

6 United Nations, Economic and Social Council, Committee on Human Rights, Advisory Services in the Field of Human Rights Situation of Human Rights in Cambodia, at 84, U.N. Doc., E/CN.4/1996/93 (Feb. 26, 1996).

7 United Nations, Economic and Social Council, Committee on Human Rights, Report of the Special Representative of the Secretary-General for Human Rights in Cambodia, at 153, U.N. Doc. E/CN.4/1998/95 (Feb. 20, 1998). 
for full disclosure of information concerning all concessions in Cambodia, including economic concessions.

Subsequently, as the impact of land concessions and corresponding human right violations continued to affect more communities, Peter Leuprecht's successor, Yash Ghai, further examined the problem with a focus on human rights violations committed by land concession companies on rural communities, especially indigenous peoples. The result of this work, the 2007 SRSG Report, provided an update on key developments since the 2004 SRSG Report, including the revised legal and regulatory framework for the granting and management of ELCs, and implementation of this framework. In the report's introduction, SRSG Ghai noted that the impact of ELCs continued to mirror patterns documented in the 2004 SRSG Report, insofar as concessions had been detrimental to the livelihoods of rural communities. On the contrary, communities had drawn little benefit from land concessions and had no effective remedy when their rights were violated. SRSG Ghai also underscored the recommendations of the 2004 SRSG Report, including a recommendation that the entire concession system be reconsidered, and that alternatives for agricultural development be pursued for the benefit of Cambodia's rural population.

Despite these and many other calls for re-examination and reform, the government has continued to grant economic and other land concessions at an alarming rate. Over the last few years, increasing numbers of land concessions have been granted to private companies, both foreign and national, for large-scale agriculture, mining, infrastructure development, eco-tourism, and special economic zones. ${ }^{9}$ Many of these concessions are granted on land inhabited by indigenous communities, including protected areas and forests.

The lack of a public assessment by the government on the impact of the concession system on local communities' human rights and livelihoods, and the environment, as well as other human and economic costs of the concession system, together with a general lack of transparency surrounding concession activity, have been the subject of increasing discontent and protest. The result has been a general lack of trust by communities towards the authorities responsible for granting concession contracts, the local

9 Licadho \& Cambodia Daily, Carving Up Cambodia: One concession at a time, The Cambodia Daily Weekend, Mar. 10-11, 2012, available at http://licadhocambodia.org/land2012. 
authorities and armed forces tasked with implementing the concessions, and the business enterprises who are viewed as exploitative and exclusive.

\section{NATIONAL FRAMEWORK: LAWS AND PROCEDURES}

There have been a number of legislative and policy developments since the 2007 SRSG Report, which build on the relatively well-developed existing national legal framework for land management. Under the Land Law of 2001, there are two categories of state land: state public land and state private land. According to Article 15 of the Land Law and the Sub-Decree on State Land Management, state public land should be used in the public interest, and includes natural resources such as forests, rivers, natural lakes, nature reserves protected by the law, and archeological, cultural and historical patrimonies. State public land is not for sale, and cannot be the subject of a land concession. When state public land loses its public interest value, it may become state private land, which can be used for other purposes. However state public land can only become state private land through declassification by a law passed by the National Assembly. ${ }^{10}$

In 2006, a Royal Decree was issued by the King to allow the government to make decisions on changing the status of state public land through a sub-decree. ${ }^{11}$ The Royal Decree requires certain conditions to be observed when changing the status of state public land, for example, the land no longer serves the public interest, has lost its originally intended function, or is no longer used directly by the public. ${ }^{12}$ This decree was followed by a sub-decree on rules and procedures for reclassification. ${ }^{13}$ The Sub-Decree on State Land Management sets out the framework for state land identi-

10 Land Law, 2001, arts. 16, 17.

11 Royal Decree, Aug. 8, 2006, on Provisional Guidelines and Provisions regarding the Expropriation of State Public Properties and of Public Entities.

12 Royal Decree No. NorSor/RoKorTor/0806/339, dated Aug. 3, 2006, on Provisional Guidelines and Provisions regarding the Expropriation of State Public Properties and of Public Entities, art. 3.

13 Sub-Decree No. 129, dated Nov. 27, 2006, on the Rules and Procedures Reclassification of State Public Properties and Public Entities. 
fication, mapping, registration and classification, including the creation and maintenance of a state land database. ${ }^{14}$

The Land Law of 2001 authorizes the granting of land concessions for either social or economic purposes. The Land Law also envisages "other kinds of concessions," including mining, fishing, industrial development and port concessions (also referred to as use, development or exploitation concessions), which do not fall within its scope. Land concessions can never be based on a de facto occupation of the land, but rather must be based on a specific legal document, issued by the competent authority prior to the occupation of the land, and must be registered with the Ministry of Land Management. ${ }^{15}$ As described above, land concessions can only be granted on private state lands. ${ }^{16}$

Social land concessions can be used to grant state private land to poor landless families for residential or farming purposes and to provide housing for army veterans. They are regulated by the Sub-Decree on Social Land Concessions. ${ }^{17}$ Other kinds of concessions, which include mining, ports, airports, industrial development, and fishing concessions, are regulated by other laws such as the 2007 Law on Use, Development or Exploitation Concessions, not the 2001 Land Law.

Economic land concession beneficiaries can clear land for industrial or commercial agricultural exploitation. The Sub-Decree on Economic Land Concessions adopted in December 2005 regulates the procedures for the granting of concessions and provides an important advance in establishing the legal and regulatory framework for the granting and management of concessions, including requirements to conduct public consultations

14 Sub-Decree No. 118 HNK/BK, dated Oct. 7, 2005, on State Land Management.

15 Land Law, 2001, art. 53; Sub-Decree No. 114, dated Aug. 29, 2007, on the Mortgage and Transfer of the Rights over a Long-Term Lease or an Economic Land Concession, art. 6.

16 Land Law, 2001, art. 58; Sub-Decree No. 19 ANK/BK, dated Mar. 19, 2003, on Social Land Concessions, arts. 2, 3.

17 Sub-Decree No. 19 ANK/BK, dated Mar. 19, 2003, on Social Land Concessions, arts. 2, 3 . 
as well as environmental and social impact assessments (two of five fundamental criteria). ${ }^{18}$

Land concessions for economic purposes include tree plantations (such as rubber, palm oil, teak, eucalyptus, and coconuts) and "agroindustry" (the large-scale production of food such as cassava, rice, corn, and soybeans). Under the 2001 Land Law, land concessions for economic purposes provide investors with exclusive rights to manage and harvest land, but may only create rights for use of the land during a fixed period of time, per the concession contract. They are granted in exchange for certain investments and fees.

Land concessions areas are limited by law to a maximum area of 10,000 hectares (ostensibly to avoid monopolization of natural resources), and a maximum duration of 99 years. Previously, provincial and municipal governments had the power to grant concessions of 1,000 hectares or less (per the 2005 sub-decree), however in 2008 this power was withdrawn by the central government. ELCs may now be granted only by national institutions. ${ }^{19}$ The government may revoke land concessions if the concessionaire does not comply with the terms of the concession contract. ${ }^{20}$ Concessions are also subject to the Civil Code provisions relating to perpetual leases except where otherwise provided by special law. ${ }^{21}$

A sub-decree ${ }^{22}$ was issued in 2007 to determine the principles, terms, and conditions for security and transfer rights granted to investors on a long-term lease or an economic land concession. Only immovable property registered in the Master Land Register can be subject to a concession and a concessionaire cannot become the owner of the land. ${ }^{23}$ The certificates

18 Sub-Decree No. 146 ANK/BK, arts. 4(3), 4(5).

19 Sub-Decree No. 131 ANKr.BK, dated Sept. 15, 2008.

20 Land Law, 2001, art. 55.

21 Civil Code, art. 307.

22 Sub-Decree No. 114, dated Aug. 29, 2007, on the Mortgage and Transfer of the Rights over a Long-Term Lease or an Economic Land Concession.

23 See Sub-Decree No. 114, arts. 5, 7, 9. The concessionaire has the right to mortgage or transfer his/her right over the land concession as well as the buildings and/or other immovable properties that he/she has constructed on the land, except as otherwise specified in the economic land concession agreement or as restricted by law. In all cases, the creditor cannot become the owner of the land and has 
of ELCs must clearly specify the category of immovable property, its size, location, the identity of the owner of the land, and the identity of the concessionaire, as well as the duration of the concession. ${ }^{24}$

The Sub-Decree on Economic Land Concessions of 2005 determines the criteria, procedures, mechanisms, and institutional arrangements for granting and monitoring the performance of ELCs. The Ministry of Agriculture, Forestry and Fisheries (MAFF) is authorized to grant ELCs. According to the Sub-Decree on Economic Land Concessions, the procedure for the granting of ELCs may be initiated through solicited proposals, where the government seeks expressions of interest in a project, or unsolicited proposals, where an investor proposes a project. However, competitive solicited proposals are the prioritized method for granting concessions, and unsolicited proposals may only be considered in exceptional cases where an investor promises to provide outstanding advantages through the introduction of new technology, contribute to social land concessions, or provide access to processing or export markets. ${ }^{25}$ ELCs should be granted when only all the following criteria have been met: ${ }^{26}$

a. the land has been registered and classified as state private land;

b. a land use plan has been adopted by the provincial or municipal state land management committee, and the proposed land use is consistent with the plan;

c. environmental and social impact assessments have been completed with respect to the land use and development plan; and

d. there are solutions for resettlement issues, in accordance with the existing legal framework and procedures. There shall be no

no right to claim ownership of the immovable property rented by or conceded to his debtor who has used his right over the concession as security. Moreover, the creditor shall not have the rights to claim the right to dispose of the immovable property possessed through a concession by his/her debtor.

24 Sub-Decree No. 114, art. 10.

25 Sub-Decree No. 146 ANK/BK, on Economic Land Concessions, art. 18.

26 Sub-Decree No. 146 ANK/BK, on Economic Land Concessions, art. 4. 
involuntary resettlement by lawful land holders and access to private land shall be respected; and

e. public consultations have been conducted with territorial authorities and local residents relating to the concession proposal.

The Sub-Decree on Economic Land Concessions also created a Technical Secretariat located at the MAFF with a mandate to support the authorities in reviewing existing ELCs, including: contractual compliance, land use fees and other revenue from contracts; a public consultation to solicit comments on concession activities within communes where concessions are located; a request for land regularization; ${ }^{27}$ and a request for the voluntary reduction of ELCs exceeding 10,000 hectares.

The Ministry of Environment (MoE) is mandated to manage Cambodia's protected areas and is tasked, among other things, with reviewing and advising the government on the environmental impact of investment projects. ${ }^{28}$ As the MAFF is authorized to grant all ELCs under Cambodian law, it remains unclear upon what legal basis the MoE is authorized to grant ELCs or other land concessions within protected areas. However, a subdecree issued by the government in 2007 allows ministries and authorities other than MAFF to sign economic land concession or long-term leases, in particular in the case where the lease is made with the royal government

27 This is the responsibility of the Ministry of Land Management, Urban Planning and Construction (MLMUPC) and includes land parcel adjustments, adjudication of land rights of the occupants of land parcels under review, and demarcation and registration of land through existing procedures.

28 Protected Area Law, 2008, arts. 2, 4. The MoE is responsible for the management of the protected areas as defined by the provisions of the Law on Environmental Protection and Natural Resources Management (promulgated by Royal Decree No NS/RKM/1296/36 of Dec. 24, 1996); Royal Decree on the Establishment and Designation of Protected Areas of Nov. 1, 1993; Royal Decree on the Establishment and Management of Boeng Tonle Sap Biosphere reserve (No. NS/RKT/0401/070 of Apr. 10, 2001). 
on untitled land and signed together with the Ministry of Economy and Finance. ${ }^{29}$

The Protected Area $\mathrm{Law}^{30}$ mandates the Ministry to set up a National Committee for Conflict Resolution on Protected Area Management (NCRPAM) and the Minister is to chair the inter-ministerial committee to resolve disputes arising from investment projects in protected areas. The Ministry is also responsible for evaluating and reviewing Environmental Impact Assessments (EIAs), and ensuring their implementation. This includes ensuring adequate follow up, monitoring, and taking appropriate measures to ensure the relevant investor will comply with a proposed Environmental Management Plan (EMP) during a project's construction, implementation, and closure, as has been described in the relevant EIA report. ${ }^{31}$

The Ministry of Industry, Mines and Energy (MIME) is tasked, among other things, with issuing mining licenses. According to the $2001 \mathrm{Law}$ on Management and Exploitation of Mineral Resources, MIME is responsible for managing and inspecting all mining operations for compliance with the law. ${ }^{32}$ There are four general types of mining licenses: Artisanal Mining Licenses, ${ }^{33}$ Pit and Quarry Licenses and Gem Mining Licenses, and Exploration and Exploitation Licenses for Industrial Scale Mining. For the Industrial Mining Licenses, the company must show that it is technically and financially able to implement the project, and the license applicant

29 Sub Decree No. 114 ANKr.BK, dated Aug. 29, 2007, on the Mortgage and Transfer of the Rights Over a Long-term Lease or an Economic Land Concession, art. 5 stated that "Only immovable property registered in the Master Land Register can be subject of a concession or long-term lease. In case the lease is made with the royal government and the land is not titled, the lease shall be signed by the Minister of the Ministry of Economy and Finance together with relevant ministers or heads of institutions, or provincial-municipal governors who are the trustee authorities of the said land."

30 Protected Area Law, 2008, art. 20.

31 Sub-Decree No. 72, dated Aug. 11, 1999, on the Environmental Impact Assessment Process.

32 Law on Management and Exploitation of Mineral Resources, 2001, article 15.

33 Applications for artisanal mining licenses are processed through the local department of MIME in the area where the mining operation is located (article 14 of the Mining Law). 
must also do the following: conduct a feasibility study and complete an EIA; create a plan for protecting the health and safety of workers; create a plan for the education, training and employment of Cambodian citizens; and prepare a plan for decommissioning (or closing down) the mine and restoring the surrounding affected environment after the mine closes. ${ }^{34}$

The 1994 Law on Foreign Investment in the Kingdom of Cambodia established the Council for the Development of Cambodia (CDC). ${ }^{35}$ According to this law, the CDC is the highest authority on private and public sector investment in Cambodia. It is chaired by the Prime Minister and composed of senior ministers from the relevant government agencies. ${ }^{36}$ The Cambodian Investment Board and the Cambodian Special Economic Zone Board are the CDC's operational arms for private sector investment, dealing with investment projects within and outside of special economic zones respectively. Both boards review investment applications, including land concessions, and grant incentives to investment projects meeting the requirements laid out in the 1994 Investment Law. As such, the CDC plays an important role in investment in land concessions.

\section{a. Ministry of Land Management, Urban Planning and Construction (MLMUPC)}

The Land Law 2001 designated the MLMUPC as the entity responsible for issuing titles relating to immovable property (land) and managing the cadastral administration of land belonging to the state, which includes state private land over which land concessions may be granted. MLMUPC is responsible for land regularization when there is a request from the ELC Technical Secretariat. This includes land parcel adjustments, adjudication of land rights of occupants of land parcels under review, and demarcation and registration of land through existing procedures. This Ministry also has the duty to register land concessions for economic and other purposes.

34 Law on Management and Exploitation of Mineral Resources, 2001, arts. 11(6), 21.

35 Law on Investment in 1994, art. 3, and Law on the Amendment to the Law on Investment in 1994, dated Mar. 24, 2003.

36 Sub-Decree No. 149, dated Oct. 3, 2008, on the Organization and Functioning of the CDC, art. 1. 
The existence of land concessions or long-term leases must be recorded on land title certificates managed by the MLMUPC. ${ }^{37}$

\section{b. Law on Protected Areas}

The Protected Area Law came into force in January 2008. It defines the framework for the management, conservation and development of protected areas (national parks, wildlife sanctuaries, protected landscapes, multiple use areas, Ramsar sites, biosphere reserves, natural heritage sites, and marine parks), ${ }^{38}$ which had been defined by previous regulations on national resource management and environmental protection. ${ }^{39}$ The law aims to ensure the management and sustainable use of natural resources, and conservation of biodiversity, in protected areas.

The 1993 Royal Decree on the Protection of Natural Areas recognized 23 protected areas. Subsequent sub-decrees have added additional sites to Cambodia's protected areas list and altered the size of the original 23 areas. At present there is no publicly available list of all protected areas and their boundaries. The 1993 Royal Decree divides the protected areas into four distinct categories: natural Parks, wildlife reserves, protected landscapes, and multi-purpose areas. These categories were expanded by the 2008 Protected Area Law to include Ramsar sites, the Tonle Sap Biosphere Reserve, natural heritage sites, and marine parks.

The 2008 Protected Areas Law also introduced a new zoning management system in order to effectively manage the conservation and development of protected areas. Zones include the core zone, the conservation zone, the sustainable use zone, and the community zone. No clearance or building is allowed in the core or conservation zones, and any development within the sustainable use or community zones can only take place with the approval of the government at the request of the Ministry of Environment

37 Sub-Decree No. 114, art. 6. The MLMUPC shall issue "Certificates of Long-Term Lease" and "Certificates of Economic Land Concession."

38 Protected Area Law, 2008, art. 7.

39 The protected areas are those defined by the provisions of the 1996 Law on Environmental Protection and Natural Resources Management, the Royal Decree on the Establishment and Designation of Protected Areas of Nov. 1, 1993, and the Royal Decree on the Establishment and Management of Boeng Tonle Sap Biosphere reserve of Apr. 10, 2001, among others. 
(MoE). ${ }^{40}$ As with any areas protected under the Protected Areas Law, any development in these areas or in areas adjacent to protected areas must first be subject to an environmental and social impact assessment. ${ }^{41}$

Modification of the boundaries of each zone can only be carried out on the basis of clear scientific information on the ecosystems which are subject to change or are under threat, in compliance with the policies and strategies of the government. ${ }^{42}$ The $\mathrm{MoE}$ is charged with mapping protected areas with the participation of the MLMUPC, local authorities, local communities, and relevant agencies. ${ }^{43}$ The Protected Area Law also set conditions for the establishment or modification of any protected area by a sub-decree. ${ }^{44}$

Chapter VI of the law determines the involvement and access rights of local communities and indigenous communities, and declares that the state recognizes and secures access to traditional uses, local customs, beliefs and religions of the local communities, and indigenous ethnic minority groups residing within or adjacent to the protected areas. The law tasked the MoE with the authority to allocate part or parts of sustainable use zones to communities residing within or adjacent to a protected area as

40 Protected Area Law, 2008, art. 36.

41 Protected Area Law, 2008, art. 44, states that "To minimize adverse impacts on the environment and to ensure that management objectives of protected areas are satisfied, an Environmental and Social lmpact Assessment shall be required on all proposals and investment for development within or adjacent to protected area boundary by the Ministry of Environment with the collaboration from relevant ministries and institutions. The procedures for Environmental and Social Impact Assessment for any projects or activities shall comply with provisions pertaining to the process of Environmental and Social Impact Assessment."

42 Protected Area Law, 2008, art. 13.

43 Protected Area Law, 2008, art. 14. The Nature Protection and Conservation Administration of the Ministry of Environment shall conduct research and management zoning with the Ministry of Environment's guidelines and demarcate the boundary markers for each protected area based on an appropriate location on the map determined by sub-decree.

Protected Area Law, 2008, art. 8. 
community protected areas. As at the end of 2011, the MoE had set up 102 community protected areas, among them 23 indigenous communities. ${ }^{45}$

\section{c. Forestry Law}

The Forestry Law authorizes the granting of forest concessions. However, since January 2002, a moratorium on logging in forest concessions has been in place, ${ }^{46}$ and the Prime Minister indicated in June 2012 that this will be continued. ${ }^{47}$ The Sub-Decree on the Management of Forest Concessions states that cancelled or revoked forest concessions must revert to natural forest protected areas, and cannot be converted into ELCs or awarded to other companies. Article 29 of the Forestry Law prohibits the harvesting of trees that yield high-value resin or those that local communities tap to extract resin for customary use. Chapter 9 of the law recognizes and ensures the traditional user rights of local communities to collect and use forest by-products. Traditional user rights include grazing for livestock and the sale of forest by-products, and do not require a permit. Chapter 9 also enables the allocation of any part of a permanent forest reserve as a community forest, granting a community living inside or near the forest the rights to manage and utilize the forest resources in a sustainable manner.

\section{d. Laws on Environment}

The 1996 Law on Environmental Protection and Natural Resource Management requires environmental impact assessments to be carried out on all private and public projects and activities. Concerned Ministries should consult with the MoE before issuing a decision or undertaking activities related to the preservation, development or management of natural re-

45 Information received during a meeting in May 2012 with the Minister of Environment. According to the Minister, of the 102 community protected areas, there are 197 villages with participation from 24,887 families. Out of the 102 communities, 23 communities or 4,449 families are of indigenous people.

46 In January 2002 the Prime Minister announced a moratorium on logging, in line with the Statement of the Royal Government on the National Forestry Sector Policy from July 26, 2002, available at http://www.forestry.gov.kh/Law/ForestPolicy.html.

47 A speech given by the Prime Minister, June 14, 2012, at the launch of the 2011 midterm review report on the implementation of the national strategic development plan update 2009-2013. 
sources. The MoE, in collaboration with the concerned ministries, must carry out a study to assess the environmental impacts on natural resources, and give recommendations to concerned ministries to ensure that the natural resources are preserved, developed, and managed in a rational and sustainable manner.

The 1999 Sub-Decree on Environmental Impact Assessment Process further specifies the procedures for an assessment which is to be done on every project or activity of any type or size, public or private, and should involve public consultations. ${ }^{48}$ It empowers the MoE to evaluate and review assessments and ensure their implementation through monitoring and surveillance. ${ }^{49}$ Article 4 of the Sub-Decree specifies that projects can only be approved by national institutions following a review of findings and recommendations provided by the MoE based on the impact assessments. At the time of writing this article, the MoE was in the process of drafting the law on environmental impact assessments, the contents of which were not made available to the public, but which were reportedly slated for a consultation process in the future.

\section{e. Law on Investment}

The Cambodian Law on Investment governs all investments made by Cambodian and foreign investors, whether individuals or legal private holdings, ${ }^{50}$ and all investment applications go through the Council for the Development of Cambodia (CDC). The Law streamlined the foreign investment regime and provided the framework for incentives (including a corporate tax exemption) for direct private sector investment, including agro-industry, infrastructure development, environmental protection, and tourism. ${ }^{51}$ Chapter six specifies that the use of land is permitted to all investors (whereas land ownership is restricted to nationals), including long-term leases of up to a period of 70 years, renewable upon request. Chapter eight notes that any dispute relating to investment should first be settled amicably through consultation between the parties, and should

48 Sub-Decree No. 72 ANRK.BK, article 1.

49 Id. at article 3.

50 Cambodian Law on Investment, Aug. 4, 1994, articles 1, 2.

$51 \quad$ Id. at arts. $12,13$. 
this not be possible within two months, the dispute should be brought by either party for Conciliation before the Council or referral to the court.

\section{f. Laws Pertaining to Mining}

The 2001 Law on Management and Exploitation of Mineral Resources governs the prospecting, exploring, and exploiting of mineral resources, save petroleum and gas, which is prohibited on "national cultural, historical and heritage sites." In addition, any mining activities in "protected, reserved or restricted" areas can only be carried out with written permission of the authority responsible for managing that area. The Law also specifies requirements for addressing environmental impact and providing fair and just compensation. The 2002 Law on Forestry allows mining within Permanent Forest Estates, however, any proposed mining operation, in addition to following other relevant laws, must be the subject of a "prior study-evaluation" by the MAFF. ${ }^{52}$

As of the writing of this article there is no specific law covering oil and gas in Cambodia, and the sector is currently governed by the amended Petroleum Regulations from 1991. Under the Petroleum Regulations of 1991, MIME was the administrative authority responsible for the management of petroleum resources. However, in 1998 this authority was transferred to the Cambodian National Petroleum Authority (CNPA). The CNPA is now responsible for evaluating bids and making recommendations to the government that Petroleum Agreements be granted to specific companies.

The Petroleum Regulations set out the terms for invitations to bid and the criteria for evaluating, negotiating, and approving subsequent bids. Exploration periods are granted for up to 4 years, after which they may be renewed twice for a period of two years each time. If exploration shows that resources can be commercially exploited, the company should apply for a production permit, including a detailed work plan and budget for the proposed exploitation. No further development of operations should commence until a production permit is issued. According to the Regulations, the production period lasts for 30 years, after which it may be extended for a further 5 years if the field is still commercially productive. A full Environmental Impact Assessment (EIA) is also required for all oil and gas operations, and project implementers are required to abide by all

52 Law on Forestry, 2002, art. 35. 
relevant legal frameworks, including the environment laws and associated regulations. Operators are also required to submit a safety management plan, emergency response plan, and an oil spill contingency plan. ${ }^{53}$

\section{g. Laws Related to Hydro-Power}

There is currently no separate law on hydropower in Cambodia, although there are a number of laws with relevance to the development and running of such projects, including the laws related to investment, electricity, land, forests, water resources, and the environment. As Cambodia does not yet have the financial or technical capacities to design, construct, and operate large-scale hydropower projects, all large-scale projects currently under development are under Build Operate Transfer (BOT) agreements of 25 years and upwards, and the existing hydro-power projects currently underway are all Chinese funded and operated. ${ }^{54}$

The first step in developing a hydropower project is to seek a Memorandum of Understanding with MIME in order to conduct and prepare a feasibility study, followed by steps to develop the project, which must be approved by the Council for the Development of Cambodia. In addition, under the 2007 Law on Water Resource Management, all hydropower projects require a water use license. ${ }^{55}$ As with all large-scale development projects, all hydropower projects must be subject to an Environmental Impact Assessment (EIA) prior to approval and EIAs should be conducted according to the procedures set out by the MoE. ${ }^{56}$

\section{h. Land Title and Possession Rights}

The dissolution of private property during the Khmer Rouge regime from 1975-1979, resulted in a lack of documentation and land titles in the primarily agrarian sector and in informal urban settlements. In recognition of the absence of widespread land registration and titling in Cambodia,

53 Reference Amendment to Petroleum Regulations, 1998.

54 Open Development Cambodia, Briefing on Hydropower, Oct. 2011, available at http://www.opendevelopmentcambodia.net/briefings/hydropower.

55 Law on Water Resource Management, 2007, article 12.

56 Law on Environmental Protection and Natural Resource Management, 1996, art. 6; Sub-Decree on Environmental Impact Assessments Process, 1999. 
Chapter Four of the Land Law recognises possession rights for peaceful, uncontested possession commencing at least five years before 2001, which can be converted into full ownership rights through the issuance of title.

The Ministry of Land Management with the support of development partners and other authorities has made significant progress in systematic and sporadic land registration and titling programmes, and has slowly made efforts to try and address the situation of informal settlers through new policies and regulations. ${ }^{57}$ The government has accelerated the land titling programme, resulting in many people obtaining ownership documents or deeds to their land. Having said this, there have been criticisms about the systematic and sporadic titling programme, Land Management and Administration Programme (LMAP), which is funded by the World Bank, GTZ (Germany), the government of Finland, and the Canadian International Development Agency (CIDA). Civil society organizations monitoring the titling scheme claim that despite significant successes in some areas, LMAP did not improve tenure security for segments of the population that are most vulnerable to displacement, as many areas of sought-after land, including that of indigenous peoples, have been systematically excluded from the programme. ${ }^{58}$ They point out that a key factor in the design of LMAP is that areas "likely to be disputed" and areas of "unclear status" would not be targeted by the titling system- in practice this has resulted in a lack of access to the titling system for households and communities that lie in the path of planned developments or concessions, or whose lands have been targeted by well connected individuals or companies. ${ }^{59}$ Consequently, they contend that "[v]ulnerable groups that have legitimate claims to land are routinely and arbitrarily denied access to land

57 E.g., note the adoption of the Circular on resolution of temporary settlements on illegally occupied land in the capital, municipal and urban areas (Circular 03) in May 2010.

58 Bridges Across Borders Cambodia, Center for Housing Rights and Evictions (COHRE), Jesuit Refugee Service, Untitled: Tenure Security and Inequality in the Cambodian Land Sector (2009).

$59 \quad I d$. at 3. 
titling and dispute resolution mechanisms, undermining the project's aim of reducing poverty and promoting social stability."60

\section{i. The Rights of Indigenous Peoples to Land}

Chapter 3 of the Land Law recognizes the rights of indigenous communities to collective ownership of their lands. The lands of indigenous communities include residential and agricultural land, and encompass both land currently cultivated and land reserved for shifting cultivation. Article 23 of the Land Law states that indigenous communities should continue to manage their communities and land according to traditional customs, pending the determination of their legal status. Once they are registered with the Ministry of Interior as legal entities, communities can apply for registration of collective title. In 2009, the government further defined its policy on indigenous peoples ${ }^{61}$ and developed the procedures to implement their rights to collective land title. ${ }^{62}$

The adoption of the Sub-Decree on indigenous land registration in April 2009 set in motion various initiatives by the Ministry of the Interior, Ministry of Rural Development, Ministry of Land Management, bilateral donors, the U.N., and NGOs to assist indigenous communities to register as legal entities (which supports community cohesiveness, traditional agricultural systems, and the preservation of culture and language) and to apply for collective land title. The Sub-Decree sets out the procedure for the communal land titling of indigenous people and includes detailed steps for communal land titling, involving boundary demarcation, surveying, public display, and reporting to higher governmental authorities.

Despite the efforts of indigenous communities to register as legal entities and eventually apply for land title, the granting of land concessions has been ongoing. As a result, in May 2011 the Ministry of Interior and

$60 \quad I d$. at 1.

61 National Policy, dated Apr. 24, 2009, on the Development of Indigenous People prepared by the Ministry of Rural Development, approved by the Council of Ministers; Circular of the Ministry of Rural Development, dated July 22, 2009, on the Procedures and Methods of Implementing National Policy on the Development and Identification of an Indigenous Community.

62 Sub-Decree No. 83 ANK, BK, dated Apr. 24, 2009, on Procedures of Registration of Land of Indigenous Communities. 
Ministry of Land Management, Urban Planning and Reconstruction issued an Inter-ministerial Circular to provide interim protective measures for indigenous peoples registered with the Ministry of the Interior. The goal of the circular is to protect the lands of indigenous peoples who are in the process of seeking collective ownership over their land, while awaiting the lengthy titling process to be completed. ${ }^{63}$

\section{j. Available Land Dispute Resolution Mechanisms}

There are five formal conflict resolution mechanisms in Cambodia for disputes relating to land rights: the Commune Councils, the Administrative Commissions, the National Authority for Land Conflict Resolution, the Cadastral Commissions, and the courts. The Commune Councils only "reconcile differences of opinion" among citizens of communes, but do not make decisions. ${ }^{64}$ Though not a requirement, in practice most cases go to the Commune Councils before they go to higher levels. The Administrative Commissions ${ }^{65}$ are a temporary structure for conciliation only pertaining to untitled parcels of land, whether claimed by private actors or the state. The unsuccessful conciliation cases are sent to the National Cadastral Commission.

The Land Law of 2001 requires disputes between possessors over an immovable property to be submitted for investigation and resolution. The results of the investigation should be submitted to the Cadastral Commission, which was established in May 2002 by a sub-decree to resolve the conflicts related to unregistered immovable property (disputes occurring outside adjudication areas and disputes arising within adjudication areas that cannot be conciliated by the Administrative Committee). The National Cadastral Commission is empowered to make decisions on disputes between possessors over unregistered land subject to possession rights, and

63 Ministry of Interior and MLMUPC, Inter-ministerial Circular, dated May 31, 2011, on interim protective measures protecting lands of indigenous peoples that has been requested for collective ownership titling, while awaiting titling process according to procedure to be completed.

64 Sub-Decree No. 22 ANK/BK, dated Mar. 25, 2002, on the Decentralization of Power, Roles and Duties to the Commune/Sangkat Councils, art. 61.

65 The Administrative Commissions arose from Sub-Decree 46 on Systematic Land Registration. 
in the case of dissatisfaction with the result, the disputants may complain to the courts. ${ }^{66}$

The Cadastral Commissions consist of the National Cadastral Commission, Provincial/Municipal Cadastral Commissions in all 24 Provinces and Municipalities, and District/Khan Cadastral Commissions in all 194 districts/khans. Only the National Cadastral Commission has decision making authority, whereas provincial and municipal levels can only mediate. The District/Khan Cadastral Commission only has authority to support reconciliation, and where no agreement is reached, a case will be referred to the provincial level for conciliation or to the national level for a decision. The parties to the conflict can appeal a decision made by the National Cadastral Commission within 30 days to the courts.

In February 2006, the National Authority on Land Dispute Resolution (NALDR) was set up by a Royal Decree. This institution, which was not envisaged when the Land Law was drafted, does not have a clear place within the existing institutional framework for land management. It is mandated to hear cases which are "beyond the competence of the $\mathrm{Na}$ tional Cadastral Commission" and receive "complaints from everywhere involving land disputes." 67 The court system (Provincial/Municipal courts, Appeals Court, Supreme Court) is only mandated to adjudicate disputes over titled/registered land using the Civil Procedure Code. Parties can bring their case to the court if they disagree with the decision made by the National Cadastral Commissions or the NALDR.

\section{k. Recent Changes in Law and Policy}

The Prime Minister instigated a number of policy developments related to ELCs in the first half of 2012. In March 2012, the Council of Ministers decided that in principle, prior to the signing of all ELC contracts, the Ministry of Land Management should register state land in the Land Registry Book following the procedures in the legal framework already in force. ${ }^{68}$ The definition of the procedure for land registration into the

66 Land Law 2001, art. 47; Sub-Decree No. 47, dated May 31, 2002, on the Organization and Functioning of the Cadastral Commission, arts. 2, 3.

67 Determination on Rules and Procedure of Work of NALDR, Dec. 11, 2008.

68 Council of Ministers, Letter No. 298 SCN.OS, dated Mar. 19, 2012. The Minister in charge of the Council of Ministers informed the ministers of the Ministry of 
Land Registry Book was designated to the MLMUPC and ELC Technical Secretariat Group of MAFF. Registration of state land for ELCs can take four to five months for large scale ELCs. The land registration service fee should follow the Fee Table set by Anti-Corruption Unit (ACU).

In May 2012, the Prime Minister issued a directive to temporarily halt the granting of ELCs, and called for a review of existing concessions. ${ }^{69}$ The directive sets out measures to strengthen and foster effectiveness for the management of ELCs. For existing ELCs, the directive instructs the relevant authorities to further implement a "leopard-skin" policy, demarcating ELCs around land already occupied, thereby aiming to lessen the effects of ELCs on communal land and decrease interruptions to the livelihood of rural communities. The directive also stated that ELCs would be cancelled for those companies that fail to comply with applicable procedures and contracts, for example companies that engage in illegal logging, encroach on land outside of the ELC, and leave the land vacant for resale. While the May 2012 directive of the Prime Minister represents a significant step in the right direction in terms of land reform, its unilateral initiation by the Prime Minister is cause for concern in terms of harmonization with the existing laws, procedures, and policies on land titling and management, and its implementation has raised a number of human rights concerns, as discussed in further detail below.

\section{INTERNATIONAL LEGAL FRAMEWORK}

Article 31 of the 1993 Constitution of the Kingdom of Cambodia enshrines international human rights obligations ${ }^{70}$ into domestic law and policy. The direct applicability of international human rights norms in Cambodian

Land Management, Urban Planning and Constructiom, Ministry of Commerce, Ministry of Environment, and the MAFF that the RGC decides in principle among other things to register state land into Land Registry Book following the procedures in legal framework in force in advance prior to the signing of ELCs contract.

69 Royal Government of Cambodia, Directive 01 Bor.Bor, dated May 7, 2012, on the measures to strengthen and foster effectiveness for the management of ELCs.

70 "The Kingdom of Cambodia shall recognize and respect human rights as stipulated in the United Nations Charter, the Universal Declaration of Human Rights, the 
courts was further confirmed by a decision of the Constitutional Council in $2007 .^{71}$ Since 2007 there have been a number of developments related to land concessions at the international level which are relevant to Cambodia's international commitments and the development of their national laws, policy, and practices.

In September 2007, Cambodia voted in favour of the United Nations Declaration on the Rights of Indigenous Peoples (UNDRIP), ${ }^{72}$ which provides an international normative foundation for the royal government's legal framework on the recognition and registration of indigenous peoples and their right to collective land title. The adoption of the Declaration represents the culmination of decades of advocacy for indigenous peoples' rights and explicitly lays out rights to land, culture, livelihood, and consultation, among other things.

The Basic Principles and Guidelines on Development based Displacement and Evictions of 2007, developed by the Special Rapporteur on adequate housing, provide a baseline standard related to the relocation of people affected by land concessions. ${ }^{73}$ The Guidelines recommend states to explore all possible alternatives to evictions and to ensure full consultation and participation of affected communities throughout the entire process, as well as provide adequate compensation and restitution. ${ }^{74}$

In 2009, at the conclusion of its first Universal Periodic Review by the United Nations Human Rights Council, the government of Cambodia

covenants and conventions related to human rights, women's and children's rights." Constitution of the Kingdom of Cambodia, art. 31.

71 Decision No. 092/003/2007, July 10, 2007.

72 G.A Res. 61/295, U.N. Doc. A/61/PV.107 (Sept. 13, 2007).

73 Basic Principles and Guidelines on Development-Based Evictions and Displacement, Annex lof the report of the Special Rapporteur on adequate housing as a component of the right to an adequate standard of living, A/HRC/4/18.

74 The Office of the United Nations High Commissioner for Human Rights in Cambodia published in December 2009 the "United Nations Commentary and Guidelines on Eviction and Resettlement" in both English and Khmer, available at http://cambodia.ohchr.org/WebDOCs/DocPublications/ EvictionsGuidelines/EvictionGuidelines-EN.pdf; http://cambodia.ohchr.org/ WebDOCs/DocPublications/EvictionsGuidelines/EvictionGuidelines-Kh.pdf. 
accepted all 91 recommendations made by member states. ${ }^{75}$ Among these, several specific recommendations were made regarding land issues, ${ }^{76} \mathrm{such}$ as the need to implement judicial reform to address land issues, intensify efforts to promote fair access to land ownership and prevent forced evictions, if not execute a moratorium, and revise policies and practices related to resettlement and relocation.

In its concluding observations on Cambodia in June 2011, the Committee on the Rights of the Child (CRC) expressed "deep concern that thousands of families and children, especially urban poor families, smallscale farmers and indigenous communities continue to be deprived of their land as a result of land grabbing and forced evictions carried out by people in positions of power," "establish a national moratorium on evictions until the determination of the legality of land claims is made."78

In its 2010 concluding observations, the Committee on the Elimination of Racial Discrimination (CERD) expressed concerns "about reports of the rapid granting of concessions of land traditionally occupied by indigenous peoples without full consideration, or exhaustion of procedures provided for, under the land law and relevant sub-decrees (arts. 2 and 5) and recommended for the government to adopt protective measures (such as granting delays when issuing land concessions). The Committee also expressed concern over the intimidation and acts of violence against indig-

75 United Nations Human Rights Council, Report of the Human Rights Council, 13th Sess., gg 355-69, U.N. Doc. A/HRC/13/56 (Feb. 8, 2011).

76 United Nations Human Rights Council, Report of the Working Group on the Universal Periodic Review on Cambodia, Recommendations 38, 60-68, U.N. Doc. A/HRC/13/4 (Jan. 4, 2010).

77 U.N. Comm. on the Rights of the Child, Concluding Observations: Cambodia, 9 61, U.N. Doc. CRC/C/KHM/CO/2 (June 20, 2011).

78 "The Committee urges the State party to establish a national moratorium on evictions until the determination of the legality of land claims is made. The Committee also urges the State party to ensure that families and their children are not made homeless as a result of evictions for private and development activities. The Committee further recommends that the State party fully implement the recommendations of the Special Rapporteur on the situation of human rights in Cambodia in relation to access to land and livelihood (A/HRC/4/36 and A/ HRC/7/42)." Id. at 62 . 
enous peoples during forced evictions or land disputes affecting them, and recommended the government to provide full protection against physical attacks and intimidation as communities seek to exercise their rights as they relate to claim communal land. ${ }^{79}$ In 2009, the Human Rights Council expressed its concern about the issues raised by disputes relating to land ownership and called upon the government of Cambodia to resolve such issues in accordance with the 2001 Land Law by strengthening the implementation of the law through the development of national guidelines to clarify relevant procedure.

Since the 2007 SRSG Report, there have been developments at the international level with regard to the state duty to protect against human rights abuses by third parties, including the private sector, and the responsibility of business enterprises. On 16 June 2011, the United Nations Human Rights Council unanimously endorsed the Guiding Principles on Business and Human Rights (Guiding Principles). ${ }^{80}$ While not a legally binding document, this endorsement established the Guiding Principles as the authoritative global reference point, clarifying business accountability and the responsibilities of the state. It should be noted that the concept of business and human rights includes efforts of corporate social respon-

79 "The Committee urges the State party to provide full protection to vulnerable groups against physical attacks and intimidation as they seek to exercise their rights as they relates to communal lands. It urges the State party to bring perpetrators of such violations to justice. In its effort to improve the judiciary, the State party should ensure greater efficiency of the judicial system to ensure equal access to justice for all, including minorities and indigenous peoples, in conformity with the Committee's general recommendation No. 31 (2005) on the prevention of racial discrimination in the administration and functioning of the criminal justice system." Id. at 17.

80 See United Nations Human Rights Council, Human rights and transnational corporations and other business enterprises, U.N. Doc. A/HRC/17/L.17/Rev.1 (June 15, 2011). The Guiding Principles on Business and Human Rights are contained in the annex to the Special Representative's 2011 report to the Human Rights Council (A/HRC/17/31), available at http://www2.ohchr.org/english/bodies/hrcouncil/ docs/17session/A.HRC.17.31_en.pdf. 
sibility but international standards impose obligations that are neither voluntary nor ad hoc. ${ }^{81}$

The Guiding Principles are grounded in recognition of states' existing obligations to respect, protect and fulfill human rights and fundamental freedoms. Therefore, the standards on business and human rights are directly relevant to the Kingdom of Cambodia through their international legal commitments and domestic law. The Guiding Principles apply to all business enterprises, both transnational and others, regardless of their size, sector, location, ownership and structure. Therefore, all businesses involved in land concessions in Cambodia (the host state), including businesses operations from foreign countries (the home states) bear the responsibility to protect against human rights violations.

The Guiding Principles are a set of 31 standards to support the implementation of the United Nations "Protect, Respect and Remedy" policy framework. ${ }^{82}$ They are the product of six years of research and extensive consultations involving governments, businesses enterprises and associations, civil society, affected individuals and communities, and investors. They highlight what steps states should take to foster business' respect for human rights, providing a standard for stakeholders to monitor and assess these steps, and show how businesses can become aware and demonstrate to others that they respect human rights and reduce the risk of causing or contributing to human rights harm. They also stipulate what both states

81 The Office of the United Nations High Commissioner for Human Rights in Cambodia, published in Dec. 2011, the "Guiding Principles on Business and Human Rights: Implementing the United Nations 'Protect, Respect and Remedy' Framework" in both English and Khmer, available at http://cambodia.ohchr. org/WebDOCs/DocPublications/Business-and-HR-Guidelines/Business\%20 and\%20Human\%20Rights_English.pdf; http://cambodia.ohchr.org/WebDOCs/ DocPublications/Business-and-HR-Guidelines/Business\%20and\%20Human\%20 Rights_Khmer.pdf.

82 The "Protect, Respect and Remedy" policy framework was unanimously welcomed in 2008 by the United Nations Human Rights Council. See Protect, Respect and Remedy: a framework for business and human rights, Report of the Special Representative of the Secretary-General on the issue of human rights and transnational corporations and other business enterprises (A/HRC/8/5); Summary of Five Multi-stakeholder Negotiations (A/HRC/8/5/Add.1) (April 23, 2008). 
and business enterprises should do to enhance access to effective remedies for those whose rights have been harmed.

The new United Nations Working Group on Business and Human Rights has undertaken the promotion of the Guiding Principles, which they explain have led to a convergence of global standards and initiatives on business and human rights, including a link with the standards of the International Standardisation Organisation (ISO) Guidance on Corporate Responsibility, OECD Guidelines for Multinational Enterprises, U.N. Global Compact, and the International Finance Corporation (IFC) Sustainability Framework, among others. ${ }^{83}$

The 2011 IFC Policy and Performance Standards on Environmental and Social Sustainability acknowledges "an emerging international consensus that the private sector has a responsibility to respect human rights," including trying to close the gap in protection against forced evictions. And most recently, the Association of Southeast Asian Nations (ASEAN) announced that the first thematic study by its relatively new Intergovernmental Commission on Human Rights would focus on business and human rights in a manner that is fully compliant with the U.N. frameworks, especially the Guiding Principles. ${ }^{84}$ The convergence of these standards is directly applicable to the Cambodian context, given the large number of business

83 United Nations Human Rights Council, Report of the United Nations Working Group on Business and Human Rights, U.N. Doc. A/HRC/20/29 (Apr. 10, 2012), available at http://www.ohchr.org/Documents/Issues/Business/A.HRC.20.29_ AEV.pdf.

84 Remarks by Rafendi Djamin, Indonesian Representative to ASEAN Intergovernmental Commission on Human Rights, at Asia Pacific Forum of National Human Rights Institutions Regional Conference on Business and Human Rights, Oct. 11-13, 2011, Seoul, Korea. 
enterprises (including international and domestic, and those wholly or partly owned by the state) involved in land concessions. ${ }^{85}$

\section{International Standards for Preventing and Addressing Human Rights Impact}

There are a myriad of standards that set out the international legal obligations of states for addressing environmental and social impact. Business enterprises are internationally obliged to carry out "due diligence," that is to identify, prevent, mitigate, and account for how they address their adverse human rights impacts. ${ }^{86}$ Not only do businesses have this responsibility, but it is the duty of the state to ensure proper management and monitoring of this function. As noted earlier, states have the duty to protect against human rights abuses by third parties in their country or area of jurisdiction. Moreover, they are obligated in their international human rights obligations to exercise adequate oversight when they contract with or legislate for business enterprises.

The process for both states and businesses should include assessing the actual and potential human rights impacts, integrating and acting upon the findings, tracking responses, and communicating how such impacts are addressed. This applies to all state and donor-operated projects and to all business enterprises, regardless of size (whether transnational corporations, conglomerates, or small and medium owned enterprises), sector, structure, ownership, or country of domicile or operation (Cambodian or foreign). In the context of land concessions, it may refer directly to the environmental and social impact-carrying out assessments with good faith participation of all those affected.

Moreover, the assessment of the impact should be participatory and development planning should be inclusive of all those potentially affected.

85 Note also that the Committee on the Elimination of Racial Discrimination, in its concluding observations in 2010, encouraged business entities engaging in ELCs "to take into consideration their corporate social responsibility as it relates to the rights and well-being of local populations." See United Nations Committee on the Elimination of Racial Discrimination (CERD), Concluding Observations: Cambodia, 17, U.N. Doc. CERD/C/KHM/CO/8-13 (Apr. 1, 2010).

86 United Nations Human Rights Office of the High Commissioner, Guiding Principles on Business and Human Rights, 17-24, U.N. Doc. HR/PUB/11/04 (2011).. 
The International Covenant on Civil and Political Rights and on Economic, Social and Cultural Rights both recognize the right of all individuals and peoples to "freely pursue their economic, social and cultural development." The United Nations Declaration on the Right to Development ${ }^{87}$ laid the foundation for participation and consultation in development processes, which was complemented by references in the United Nations Declaration on the Rights of Indigenous Peoples, which upholds free, prior, and informed consent. ${ }^{88}$ This language has been incorporated into other international standards, for example the 2011 update on IFC Policy and Performance Standards on Environmental and Social Sustainability. ${ }^{89}$ In addition to the international human rights obligations of states and businesses, there are practical, operational, and logistical reasons for incorporating these requirements in business and development activities, and many governments have incorporated these standards into their national laws and policies, and companies into their standard operations. ${ }^{90}$

\section{THE LAW AND THE PRACTICE: CONCESSIONS AND COMPLIANCE WITH LEGAL REQUIREMENTS}

Given the relatively well-developed legal and policy framework governing the granting and management of economic and other land concessions, as outlined in section three, it is difficult to reconcile the current practice

87 G.A. Res. 41/128, U.N. Doc. A/RES/41/128 (Dec. 4, 1986). Article 1 states that everyone is "entitled to participate in, contribute to, and enjoy economic, social, cultural and political development."

88 U.N. Declaration on the Rights of Indigenous Peoples, art. 32(2). For a practical guide on FPIC, see Oxfam, Guide to Free, Prior and Informed Consent (July 27, 2010).

89 IFC, performance standard 7.

90 For commentaries on the utility of human rights policies for businesses, see Business and Human Rights Resource Centre, "Commentaries on human rights policies," available at http://www.business-humanrights.org/ToolsGuidancePortal/Policies/ Commentaries. For a list of companies which have incorporated human rights into their statements, see "Company policy statements on human rights," available at http://www.business-humanrights.org/Documents/Policies. For a list of member companies of the Global Business Initiative on Human Rights, see http://www. global-business-initiative.org/Members.html. Of these members, at least Chevron, 
in the granting and management of ELCs. The promotion of private sector investment appears to have taken precedent over compliance with the requirements of the law, resulting in the granting of large tracts of land in protected areas, on the land of indigenous peoples, and in primary forest areas. Moreover, there is a lack of transparency, oversight and public monitoring, and reporting in relation to the concessions granted.

There is evidence that makes it appear that concessionaires have been allowed to circumvent the 10,000 hectare limit on concessions through the acquisition of contiguous plots used for the same purpose; in some cases, the same company, sometimes using the name of a family member or affiliate, has been able to hold as concessions adjacent parcels of land by registering their land separately. Most concessions granted since the promulgation of the 2001 Land Law do not exceed the 10,000 hectare limit, but the 2007 SRSG Report cited nine ELCs that surpassed the limit. ${ }^{91}$ While difficult to track (according to the most recent MAFF list, no ELCs exceeding 10,000 hectares have been granted since the 2007 SRSG Report), there are several possible new violations.

Another phenomenon is the illicit use or non-exploitation of land after a land concession has been granted. Chapter Two of the National Strategic Development Plan Update states that "land concentration and landless people are on a rising trend, adversely impacting on the equity and efficiency of land use. On the other hand, large areas under economic land concessions have not been utilized efficiently as targeted, needing strict government measures to tackle them." ${ }^{92}$ While some in the government are aware of and have made efforts to combat this problem, resulting in the cancellation of land concession contracts in some cases, there has been

Sime Darby, General Electric, Unilever, Coca Cola, Novo Nordisk, and Total operate in Cambodia.

91 SRSG 2007 report, at 11.

92 National Strategic Development Plan Update, at 10. 
irregular oversight over the use of land granted through concessions, with inadequate management and monitoring.

\section{a. Expropriation of State Public Land, State Private Land and Land Use Plans}

In recent years many land concessions have been granted within protected areas by means of a sub-decree. ${ }^{93}$ There is concern that the sub-decree has been used as a means for the government to designate land within a protected area which is state public land and to reclassify it as state private land to then be leased to private companies. Upon review of the sub-decrees published in the Royal Gazette, it appears that they have been issued to designate parcels of land as "sustainable use zones" within protected areas with no prior assessment provided as to whether the areas qualify as sustainable use zones or community zones. It should be noted here that these are the only two types of land in protected areas with possibility of use as land concessions, pending the fulfillment of criteria. Moreover, as the name of the company is often mentioned in the sub-decree (often with reference to prior written correspondence), a reasonable observer would conclude that an arrangement has already been made between a prospective company and the Ministry of Environment (MoE). In a number of instances, some weeks or months following the initial sub-decree, a further sub-decree is issued which classifies the assigned "sustainable use zone" land as private state land, thereby ensuring its eligibility to be granted as a land concession. This has raised the question as to whether it is legal under the existing domestic legal framework for the government to reclassify state public land without going through the Parliament.

Under the 2008 Protected Area Law, the MoE is authorized to establish or modify protected areas according to specific criteria and following careful review of access to natural resources and land use. The proposal for establishing or modifying a protected area is determined by a subdecree. At the time of writing, there was no information that the MoE had established or formally modified any protected area, but it increased the number of land concessions, including ELCs, mining concessions, and

93 A sub-decree (Anu-Kret) is adopted by the Council of Ministers and signed by the Prime Minister. A sub-decree must be in strict conformity with the Constitution and conform to the law to which it refers. 
large scale development projects, among other concessions, that have been granted within protected areas.

Both the Royal Decree of 1 November 1993 on the Protection of Natural Areas, and the 2008 Protected Areas Law allow for the modification of the boundaries of each zoning system, which has to be done based on a scientific review of the ecosystem and compliance with existing policies. However, as is reportedly often happening in practice, the systematic zoning for most protected areas is not formally determined when a parcel of land is being considered for a concession or development project. Rather, it appears that the zoning within a protected area is decided upon after the granting of land concessions. Most of the government sub-decrees which serve to reclassify proposed areas for concessions within protected areas only state that "land has been determined as a sustainable use zone," but do not mention the type of zone of the land area prior to its reclassification.

The law also prohibits clearance or building in the core or conservation zones, and any development within the sustainable use or community zones can only take place with the appropriate approval from the government at the request of the MoE. Any development in these areas or in areas adjacent to protected areas must first be subject to an environmental and social impact assessment. While there is a need for further clarification from the MoE regarding systematic zoning, it has been reported that many concessions have already been granted in the central parts of some protected areas where there is primary forest. For example, Licadho has published data stating that 22 percent of the Boeng Per Wildlife Sanctuary has been covered by a rubber plantation. ${ }^{94}$

\section{b. Public Consultations and Environmental and Social Impact Assessments}

As described in detail above, under the Cambodian legal framework, the essential pre-conditions to granting land concessions are public consultations together with environmental and social impact assessments. Assessments are to be undertaken and reviewed and the findings shared before the granting of concessions. As mentioned in the 2007 SRSG Report, in most cases, adequate public consultations (entailing good faith efforts to

94 Licadho map published in The Cambodia Daily (No. 730, Saturday and Sunday, Mar. 10-11, 2012). 
engage with all affected parties and reach a mutually agreed upon solution) have not been conducted prior to the granting of the concessions, with decisions affecting the land on which communities live being made without their involvement. Similarly, in most cases, genuine environmental and social impact assessments have generally not been undertaken before the granting of land for investment (or have been undertaken in some cases but not shared with affected communities), and concessions that have been granted since 2007 seem to reflect this trend.

According to the National Strategic Development Plan Update, in 2008 the MoE in collaboration with other ministries and concerned parties reviewed and provided recommendations on environmental and social impact assessment reports for 37 public and private projects, but only 15 reports in the agricultural, industrial, energy, tourism, and infrastructure sectors have been endorsed. The MoE also signed agreements with 61 project owners on environmental protection. ${ }^{95}$

\section{c. Compliance with the Legal Protections for the Land of Indigenous Peoples}

The 2001 Land Law enshrines the rights of indigenous peoples to land and the adoption of the Sub-Decree on indigenous land registration in April 2009 set in motion various initiatives by the Ministry of the Interior, Ministry of Rural Development, Ministry of Land Management, bilateral donors, the U.N., and NGOs to assist indigenous communities to register as legal entities and apply for collective land title. A pilot project was then launched in 2009 to secure the collective land title of three indigenous communities in Rattanakiri and Mondulkiri provinces, and in December 2011, these communities received the first collective land titles in Cambodia.

Although these are positive steps for the protection of the land, culture, language, and traditions of these communities, there are many more communities across 15 provinces which are in need of support for the protection of their lands in the face of unregulated development on their traditionally occupied land. The granting of concessions on land traditionally used by indigenous peoples affects their ability to register their land and their access

95 National Strategic Development Plan Update, at 38, 125. 
to the surrounding areas, in turn affecting their livelihood and ability to search for food, and the practice of their traditional and cultural rights.

Moreover, despite robust laws and policies at the national level, this process is entirely dependent on external donor aid and uneven political will on a case by case basis. It also requires the availability of field-based civil society organizations in the provinces for implementation. According to information on ongoing projects provided by ILO, who coordinates the initiatives, while areas with high populations of indigenous peoples such as Mondulkiri, Rattanakiri and Preah Vihear provinces have received the most attention and bilateral and multilateral financial assistance by GIZ, Danida, OHCHR, and others, initiatives to expand to other provinces is slow due to limited capacity and resources.

There are reportedly a myriad of challenges with the procedural requirements for registering as a legal entity and applying for collective land title, which is lengthy and over-burdened by bureaucratic steps. While the relevant policy envisages a process "simple in both administrative and technical aspects," ${ }^{96}$ in practice, there are currently eleven steps for legal registration and application for title, including various procedures involving national, provincial and local authorities in the self-identification of communities, community appraisal, and land demarcation and mapping (results publicly displayed). A positive aspect of the process is that the procedures are taking place with the participation of a range of stakeholders and with the full involvement of communities, and this is to be warmly welcomed.

Given the lengthy procedure for the registration of indigenous land, the May 2011 Inter-ministerial Circular, which provides interim protective measures for indigenous peoples registered with the Ministry of the Interior, is a welcome development. In effect, it should have halted the granting of land concessions on land traditionally occupied by indigenous peoples. For example, the Phnong peoples from four villages in the Keo Seima district, Mondulkiri province have been granted protection by the Mondulkiri provincial governor in 2011 and 2012 while undergoing their application for collective land title.

Nevertheless, there is one unfortunate loophole to the Circular, which in practice has served to ensure its broad non-implementation. The interim

96 Policy on Registration and Right to Use of Land of Indigenous Communities in Cambodia, art. 4. 
protective measures exclude plots that the royal government has agreed in principle for investment or development before the Circular came into effect in May 2011 (so that any impact on legal private and public ownership of lands that have been legally occupied and agreed in accordance with legal provisions could be avoided). As a result, given the irregular granting of land concessions and successful efforts to circumvent the legal framework, the Circular has had minimal impact. Furthermore, the requirement for the recognition of indigenous peoples by the Ministry of Interior effectively pertains to only a very small number of communities who have benefited from development partner assistance.

\section{THE BENEFITS AND NEGATIVE IMPACTS OF LAND CONCESSIONS}

Cambodia as an emerging market has a stated objective of increasing exports and exploiting its natural resources for the purposes of development. As regards ELCs specifically, the National Strategic Development Plan Update specifically places priority on improving agricultural productivity and diversification. ${ }^{97}$ Power generated by Cambodia's proposed hydropower projects will not only generate energy but also revenue, and the power will not only be used for domestic consumption but a share will also likely be exported. There are economic and social benefits that land concessions have brought to Cambodia, such as job creation (and therefore a more dynamic local market), tax revenues, and new roads and other upgrades in infrastructure. Some land concession companies participate in conservation and environmental training programmes. Some associated benefits for communities in concession areas include health posts and schools.

However, no comprehensive evidence-based report has been officially published about the benefits of land concessions, and the amount of new employment and physical investment can often be well below expectations. Moreover, there is no evidence that revenue generated from land concessions has been used by the government in concession areas for social and economic development, such as in the health and education sectors, or in infrastructure development, or has been used to alleviate poverty. On the contrary, the government continues to be dependent on foreign aid. Data and analysis on revenue generated from land concessions and the attendant

97 National Strategic Development Plan Update, Ch. Four, at 121. 
benefits to the population is an area for further development. By contrast, the negative impacts have been well documented.

\section{Overall human rights impacts}

Regrettably, the human rights impact of economic and other land concessions continues along the same trends that were documented in the 2004 SRSG and 2007 SRSG reports. The impacts are numerous: the destruction of the environment due to bulldozing, clearing of land and planting of nonnative plants; the lack of consultation with local communities, contributing to their marginalization and conflicts with companies and local authorities; the undermining of efforts to register indigenous peoples as legal entities so that they can preserve their culture, language and traditional agricultural practices, and apply for collective land title; encroachment on farm land and areas of cultural and spiritual significance; the loss of traditional livelihoods and the perpetuation of a gross income disparity (rural poor as compared with wealthy concessionaires and those benefiting financially from the concessions); access to clean water and sanitation; forced evictions, displacement, and relocation of people from their homes and farm lands, creating difficulties with finding or sustaining employment, income-generation and access to basic services; sub-standard labour conditions; militarization of land concessions, contributing to intimidation and violence by armed security guards, who are sometimes members of the Royal Cambodian Armed Forces and other times privately employed; and a lack of effective remedy or recourse for affected communities.

As land concessions are granted, the communities living on the land are often subjected to forced eviction, involuntary resettlement or unplanned relocation. Eviction and relocation, whether forcible or not, can often increase poverty and debt, and limit access to income generation. Other problems include the lack of access to water, sanitation, health services and education, physical and mental health problems, challenges to realizing civil and political rights (e.g. voting, access to remedy), and social stigmatization and disruption to communities and family cohesiveness. Policies, procedures, and safeguards which prevent forced eviction are either lacking or not enforced, compensation schemes are either misman- 
aged or inadequate, and relocation efforts are seldom adequately planned with sufficient resources and foresight.

Domestic law and international law restrict displacement and relocation, and provide guidance if relocation is not avoidable. However, forced eviction and resettlement of local communities due to land concessions or large-scale development and infrastructure projects have been conducted without due process of law and safeguard for the rights to land and housing of the resident population. In some cases, force has been employed to carry out the eviction or relocation, and often at the behest of foreign companies. Furthermore, it is unclear who is financing the evictions.

Land concessions, whether ELCs or mining concessions, as well as large scale development projects have had a devastating impact on non-indigenous and indigenous communities alike, but the indigenous communities, whose rights to collective ownership of land are protected under domestic law and international law, are particularly vulnerable. The encroachment of their land is undermining the ability of indigenous communities to register their collective ownership of traditional lands, and enforce their rights to collective land title under the 2001 Land Law.

While indigenous peoples are reported to inhabit fifteen provinces, two thirds of the indigenous population of Cambodia are found in the northeastern provinces of Ratanakiri and Mondulkiri, forming the majority of the population in both provinces. There are already many cases where the concessions are being developed directly on indigenous land and oftentimes there is little land or no land left for the indigenous community to register. The development of agro-industry is threatening the traditional agricultural systems of indigenous peoples, and therefore their food security. New farming techniques have been brought in on indigenous land, without the consultation of the communities that are most familiar with the areas. While they are often offered jobs on the new plantations-indeed there is typically a shortage of labour in remote areas-many indigenous communities have reportedly not adapted to this new way of farming. In addition, they are unable to communicate in Khmer or the language of the foreign company, and local tensions related to the expropriation of land and management of the plantations have arisen. Labour conditions are not well-monitored and reportedly below domestic and international standards. As mentioned earlier, the granting of economic land and other concessions has also undermined the work of development partners, not 
only those working to assist the communities to register and gain collective titles, but also many development organizations and NGOs that have been trying to help improve the livelihoods of rural communities and indigenous peoples.

The granting of land concessions has particularly impacted certain areas, such as those related to labour, livelihood, security, and family structure and roles. Concessions contribute to the reduction of land and forest for inhabitants, causing shifts in opportunities for livelihood, and changes in labour and migration patterns. The lack of resources is exposing villagers to problems in food scarcity, and many communities must leave their area to search of work. For example, in Kratie, where the majority of ELCs have been granted, men move to other provinces in search of forest products no longer available in the local province. Women move to nearby areas to work as labourers in plantations or as domestic workers or labourers in Malaysia, for example. ${ }^{98}$ In cases where labour opportunities as plantation workers would only be seized by male members of the communities due to cultural reasons, this could lead to a further marginalisation of women, who are generally more prone to poverty and undernourishment.

For both Khmer and indigenous women and girls in remote rural areas, with the new presence of "outsiders" (Khmer not from the area and foreigners working for the concession companies), another concern is safety, in terms of potential robbery, theft, and physical violence, including rape. This is especially important for women who traditionally go to the forest to collect food and non-timber forest products. Some women have reported that they now move in groups.

Women, children, and the elderly are often on the frontlines at protests. Women involved in the Boeung Kak Lake dispute have been especially active. ${ }^{99}$ Previously, it was assumed by communities that women and children are less likely to be targeted by authorities and they are therefore the leaders in demonstrations, but there have been increased cases of arbitrary detention and violence against female protesters. In recent months, women have taken increasingly drastic public actions to defend against the use of

98 Margherita Maffii, Women's Leadership: A case study in Cambodia, supported by the Heinrich Böll Foundation (July 2011) available at http://www.kh.boell.org/ downloads/Women_leadership_case_study_report_July_2011_1_FINAL.pdf.

99 Amnesty International, Eviction and resistance in Cambodia: Five women tell their stories (Nov. 2011). 
force by the gendarmerie; the Boeng Kak Lake women who bared their breasts, ostensibly to avoid apprehension by the police in March 2012 was particularly alarming. ${ }^{100}$

Women activists involved in land claims report harassment and intimidation against themselves and their families, which has taken a toll on their family relations and psychological welfare. Many women report feelings of hopelessness and depression, suicidal feelings, and divorce and separation related to their land disputes and involvements in land claims.

Women, who are responsible for both livelihood and caretaking of the family under duress, continue to suffer disproportionately in the eviction and relocation process. ${ }^{101}$ Where there are problems with access to basic services, such as water and sanitation, women and children are often disproportionately affected because they spend more time at the sites. In the case of urban land concessions resulting in eviction, women lose jobs and sources of livelihood more so than men, especially if relocated far from the city centre, and the same work at the relocation site does not enable them to earn the same standard of living as in high-density urban areas. With loss of income and the difficulties linked to relocation, drinking alcohol is reportedly more prevalent, and in many cases related to increased domestic tensions and violence. Unplanned parenthood at resettlement sites is also reportedly widespread.

The overwhelming impact on children is related to the deteriorated livelihoods associated with land tenure insecurity, environmental destruction and land encroachment, and forced eviction and resettlement. These affect their access to basic services, such as healthcare, adequate water and sanitation, as well as their educational opportunities. In cases of relocation, either children have dropped out of school or families had to separate to keep children in the city centre to finish the school year. Families also have had to pay informal fees to transfer their children between schools,

100 Amnesty International, Cambodia: Imprisoned for speaking out, update Phnom Penh’s Boueng Kak Lake, $\$ 3.4$ (2012), available at http://www.amnesty.org/ en/library/asset/ASA23/010/2012/en/53ead91b-9f6d-4640-9585-4f6556944b77/ asa230102012en.pdf.

101 See COHRE, A survey on the impact of forced eviction on women in Phnom Penh (2011). 
and the daily informal fees requested by teachers place an extra-burden on families' limited income.

Moreover, there are issues with child labour. For example, a study revealed that children have been pulled out of school in order to work and raise money for their struggling families due to the impacts caused by land concessions. ${ }^{102}$ As with the impacts on women and girls described above, the need to earn a livelihood can cause a breakdown in the family structure, domestic violence, and absent parents. Unplanned parenthood has resulted in many families having children who they cannot afford to feed or send to school. Overall, the impact of displacement and relocation can be very traumatic for children.

\section{ACCESS TO AN EFFECTIVE REMEDY}

As described above, there are several non-judicial and quasi-judicial mechanisms for dispute resolution, including the various levels of the cadastral system. However, the time-consuming administrative and procedural burden, financial costs associated with submitting a complaint (although there are no official fees, as with courts, transportation, lost wages, legal assistance, and so on, can prove costly for individuals), and a lack of faith in the system means that these mechanisms being used inconsistently. Complainants report that decisions by such bodies are inconsistent, irregular, and subject to political interference.

As an alternative, complainants often seek the help of individuals (e.g., local and provincial authorities, such as commune chiefs and district chiefs, as well as Oknha or tycoons) and government authorities who they view as influential and wealthy. Communities frequently make public pleas to the King and the Prime Minister and his wife for a resolution to their dispute, including submitting petitions and demonstrating in front of the Royal Palace, National Assembly, Senate, Council of Ministers, and the Prime Minister's residence. Following the exhaustion of other methods with no response or satisfactory response, there has also been a trend to participate in traditional ceremonies and prayers. Many of them also submit individual

102 E.g., on the Koh Kong Sugar Plantation. See APRODEV, Stolen Land Stolen Future, A Report on Land Grabbing in Cambodia (2011). 
or group petitions to me or come to see me during my visits to the country asking me to intervene.

Cambodia has no independent national human rights institution, but there is an inter-ministerial committee charged with coordinating human rights activities for the government: the Cambodia Human Rights Committee. The Committee's mandate to monitor and investigate individual and group complaints of human rights violations, including those related to land concessions is still pending. ${ }^{103}$ Their capacity is limited and, while they review cases, they do not often investigate cases of land disputes at the field level. Field-based case analysis in cooperation with governmental authorities and legal aid organizations on land disputes has been targeted as an area for further development. ${ }^{104}$

Owing to an uneven application of the relatively well-developed legal framework governing land rights, and an inadequate access to remedies, communities are becoming increasingly frustrated and disillusioned by formal judicial and administrative processes. Demonstrations and protests by affected communities in the capital and provinces are increasing and have become more violent. Concession-affected communities have become increasingly vocal about their complaints, filing petitions and seeking judicial redress at the provincial and national levels, organizing demonstrations in provincial capital cities and in Phnom Penh, forming road blocks, and, when all else fails, engaging in violence out of desperation.

The proliferation of displays of discontent around the country related to land disputes point to inadequate consultation and negotiation with those affected. Early and inclusive consultation can address the tensions before they escalate and contribute to preventing disputes. The United Nations Guiding Principles on Business and Human Rights promotes the use of "operational-level" grievance mechanisms to facilitate addressing disputes early and directly. These mechanisms should be accessible directly to in-

103 A sub-decree outlining their mandate is still pending, and at present most of their activities are related to capacity building on general human rights at the provincial level.

104 Note that the President of the CHRC suggested in a June 2010 meeting to form an ad hoc informal group to examine outstanding land disputes. See United Nations Human Rights Committee, Report of the Special Rapporteur on the situation of human rights in Cambodia, 32, U.N. Doc. A/HRC/15/46 (Sept.16, 2010) (prepared by Surya P. Subedi). 
dividuals and communities who may be adversely impacted by business activities, and are typically administered by business enterprises alone or with the collaboration of local authorities and civil society organizations. ${ }^{105}$ Special care should be taken to deal with language barriers (especially given the extent of foreign-owned concessions and that many indigenous peoples do not communicate in Khmer).

Some concession companies have set up procedures to deal with local level disputes and complaints, which can be an effective way of directly addressing misinformation and addressing tensions before they escalate. For example, Grandis Timber mapped out the land occupied by communities at the commencement of the concessions' activities and employed a community relations manager to deal with land and labour disputes. ${ }^{106}$ However, if measures are set up only late in the dispute, they may lose their effectiveness, especially if mistrust has already been fostered. For example, a Tripartite Committee was set up in late 2009 by Socfin-KCD in the Bousra commune, Mondulkiri province. The initiative, which in principle is to be welcomed, has been criticized for being an ineffective communication channel to address grievances. ${ }^{107}$ In addition, local efforts at dialogue that do not directly involve company representatives may hamper their potential success.

\section{CONCLUSIONS}

As can be seen from the analysis in the preceding paragraphs, the majority of the challenges in Cambodia with regard to the granting and management of economic and other land concessions derive from a failure to properly apply the domestic legal framework - that is, the laws, policies and regulations that the government itself has developed. The granting and management of economic and other land concessions in Cambodia suffer from a lack of transparency and adherence to existing laws. Much of

\footnotetext{
105 Guiding Principles on Business and Human Rights, supra note 86, at 28-31.

106 Grandis Timber Limited, Manual of Plantation Establishment Rules, Registration of Permanent of Residents and Mapping of Land Occupied (Dec. 21, 2009).

107 FIDH report, $\$ 5.6$.
} 
the legal framework on these matters is relatively well developed on paper, but the challenge is implementation in practice.

Further, a pervasive problem that exists in this regard is the uneven access to information, which has contributed to concessions benefiting only a minority, as well as a proliferation of land related conflicts, which has the potential to contribute to instability. The government should be transparent in granting and rigorous in monitoring land concessions, especially when negotiating concession agreements with both foreign and national companies, avoid conflicts of interest, hold concession companies to account by exercising oversight over their activities, and resolve land disputes. In particular, the absence of transparency in such matters has bred suspicion of corruption at all levels of the government and has fueled resentment on the part of many Cambodian citizens.

Cambodia, as an emerging market, risks developing an international reputation for insecure investment in the land sector and in general. The current climate of development is characterized by low transparency and uneven access to information, inadequate consultation and participation which is not inclusive, and, in my view, is unsustainable and likely to hamper future national economic growth. Of course, some cases of land concessions seem to have had positive impacts for the people of Cambodia in terms of job creation, stimulation of the local economy, generation of revenue to finance public services, and overall contribution to national growth. However, the human cost of many concessions has been high and human rights should be at the heart of the granting and management of land concessions in order for them to have a positive impact.

The impacts of land concessions should be analyzed for both their short- and long-term consequences; indeed, any benefits should be genuine and outweigh costs for the majority in order to be considered substantial. The development of Cambodia's land and natural resources could have a positive impact on the lives of all Cambodians if undertaken in a sustainable and equitable manner and within the framework of the human rights obligations of Cambodia. To this end, the government should make information concerning land investments, land deals and bidding processes, reviews of proposals for land concessions (and the decision-making criteria for acceptance or denial of proposals), and future plans (including on commencement of concession activity) publicly accessible. Such information could be made available on public display at the provincial level and on 
official governmental web sites. The process of re-classifying land as state private land and designating protected areas as sustainable use zones should be conducted in an atmosphere of transparency and openness by all concerned actors.

All relevant government bodies and business enterprises should adhere to the legal requirements for public consultation. Such consultations should be meaningful, inclusive, and accessible to affected people. Communities on land to be affected by the granting of a land concession should be consulted at the earliest stage on the land use plan and included in the decision-making process. Due consideration should be given to the current livelihood activities of the community and all efforts made to avoid their disruption. Standards of free, prior and informed consent should be rigorously applied when consulting with all indigenous peoples.

Concessions that are found to be exploitative, inactive or otherwise violating the conditions of the concession agreement should be cancelled, as per the relevant laws. Companies of all sizes, structures and modes of operation, both domestic and foreign, whether wholly or partly owned by the state, should address their human rights impact by practicing due diligence, including implementing measures to identify, prevent, and mitigate adverse human rights consequences, and account for their business activities. In the case of foreign-owned companies, the home states should ensure that representatives of private business enterprises under their jurisdiction do not contribute to adverse human rights impacts by regular monitoring and oversight. Finally, given the seemingly intractable status of long-standing land disputes and the proliferation of new disputes, efforts should be made to enhance effective and legitimate operational level grievance mechanisms, and involve communities and their representatives (communities may decide whether civil society organizations should be involved) at the early stages of the granting of a land concession and include them in the planning process. 